International Journal of Science
and Engineering (IJSE)
Home page: http://ejournal.undip.ac.id/index.php/ijse

\title{
Standardization of The Electricity and Economics Potentials of Landfill Gas (LFG) in Lagos, Nigeria
}

\author{
* Akujieze, C. N., and Idehai, I. M. \\ Department of Geology, Faculty of Physical Sciences, \\ University of Benin, Benin City, Nigeria \\ *Corresponding author: chrisakujieze@gmail.com
}

\begin{abstract}
Globally, various practical data and scholarly estimations of the electricity potentials of landfill gas (LFG) have been forwarded and these can be juxtaposed for estimations in the megacity called Lagos. The calculated values were between 63.22$700 \mathrm{MW}$ of derivable electricity. However, in order to limit observable disparities and ambiguities in these derivations and thus allow for more accurate projections, these estimations can be gauged using as template; -stoichiometry, establishing $50 \%$ of landfill gas as methane, assuming $50 \%$ of this volume as recoverable, and using a proposed engine efficiency of 30\%. This standardization projects a theoretical mean achievable electrical power of $121.69 \mathrm{MW}$ for the Lagos area from a population of about 21 million with a generation per capita (GPC) of $0.63 \mathrm{~kg}$ with biodegradable content of about $60 \%$. The yearly electrical energy was placed at $1,066,004.4 \mathrm{MWh}$ with tariff revenue in excess of US\$106.6 million /yr. An accruing carbon credit of about US\$75.59 million /yr is expected from certified emission reduction (CER). The projected derivations can be used as models for evaluation of the landfill gas and electricity potentials in many parts of the world.
\end{abstract}

Key words - Carbon credit; electrical power; landfill gas (LFG)

Submission: March 30, 2014

Corrected : April 20, 2014

Accepted: May 10, 2014

Doi: 10.12777 ijse.7.1.1-9

[How to cite this article: Akujieze, C. N., and Idehai, I. M. 2014. Standardization of The Electricity and Economics Potentials of Landfill Gas (LFG) in Lagos, Nigeria. Internat. J. Sci. Eng, 7(1):1-9; Doi: 10.12777/ijse.7.1.1-9

\section{INTRODUCTION}

Anaerobic degradation of biomass in the Lagos landfills in the presence of excess water, bacteria and a $\mathrm{pH}$ of about 7 produces methane which can be harnessed for electricity.

Globally, several studies have been done to estimate methane production out of municipal landfills. These are mostly based on Monod first order decay equations which are called first order decay models. First order models have a linear relation with maximum potential of methane production per weight unit of waste as well as an exponential relation with decay rate and time. A few models are classified as zero order models in which methane production is assumed to be fairly constant against time (Kamalan, et al., 2011).

However, in order to limit observable disparities and ambiguities in these derivations and allow for a more accurate projection, these estimations can be standardized using as template: stoichiometry, establishing $50 \%$ of landfill gas as methane, assuming $50 \%$ of this volume as recoverable, and by using engine efficiencies of $30 \%$.

Methane is lighter than air and can accumulate beneath structures and buildings, resulting in vegetational stress and toxicity due to $\mathrm{H}_{2} \mathrm{~S}$ and volatile organic compounds (VOCs), corrosion due to $\mathrm{CO}_{2}$-created acidity, greenhouse gases and air emissions. It is explosive above 5 to $15 \%$ by volume and causes subsurface migration offsite (up to $150 \mathrm{~m})$.

Lagos has about $27.4 \%$ of the country's urban population but which has had its electric power allocation plummeting from over 800MW ( of the country's $4,000 \mathrm{MW}$ ) in the last decade to below $300 \mathrm{MW}$ in 2011 (Suberu et al., 2012) is in dire need of alternative energy sources. An added incentive for methane exploitation schemes in landfills is that it attracts carbon credits based on the Kyoto Protocol. The environmental benefits of methane capture are expected to be exponentially higher in terms of green house gas mitigation. Therefore, the accurate estimation of this resource is important in view of exploitation designs and projections in the Lagos area.

The thrust of this study is to standardize some previous attempts at the estimation of the green energy potential \& environmental benefits of the landfill gas (LFG) from around the globe for estimations in the Lagos area. It also attempts to establish a benchmark and threshold for these estimations in the Lagos context using stoichiometry and gas laws. 


\section{MATERIALS AND METHODS}

The study was undertaken after a reconnaissance geological assessment of all the government operated landfills areas in Lagos to ascertain their suitability for landfill gas capture. The Lagos Waste Management Authority (LAWMA) is the Government Agency statutorily charged with Solid Waste Management in Lagos State. It is saddled with the responsibility of collecting, transportation and general handling of all the solid waste generated from different sources within Lagos. Given its associated successes in the current political dispensation, the LAWMA's model is being replicated in such places as: Federal Capital territory (Abuja) Ogun State, Plateau State, Ekiti State, Cross Rivers State, Osun State, Banjul, Gambia, Accra Metropolitan Authority (Ghana), City of Freetown (Sierra Leone), Addis Ababa, Ethiopia,etc.

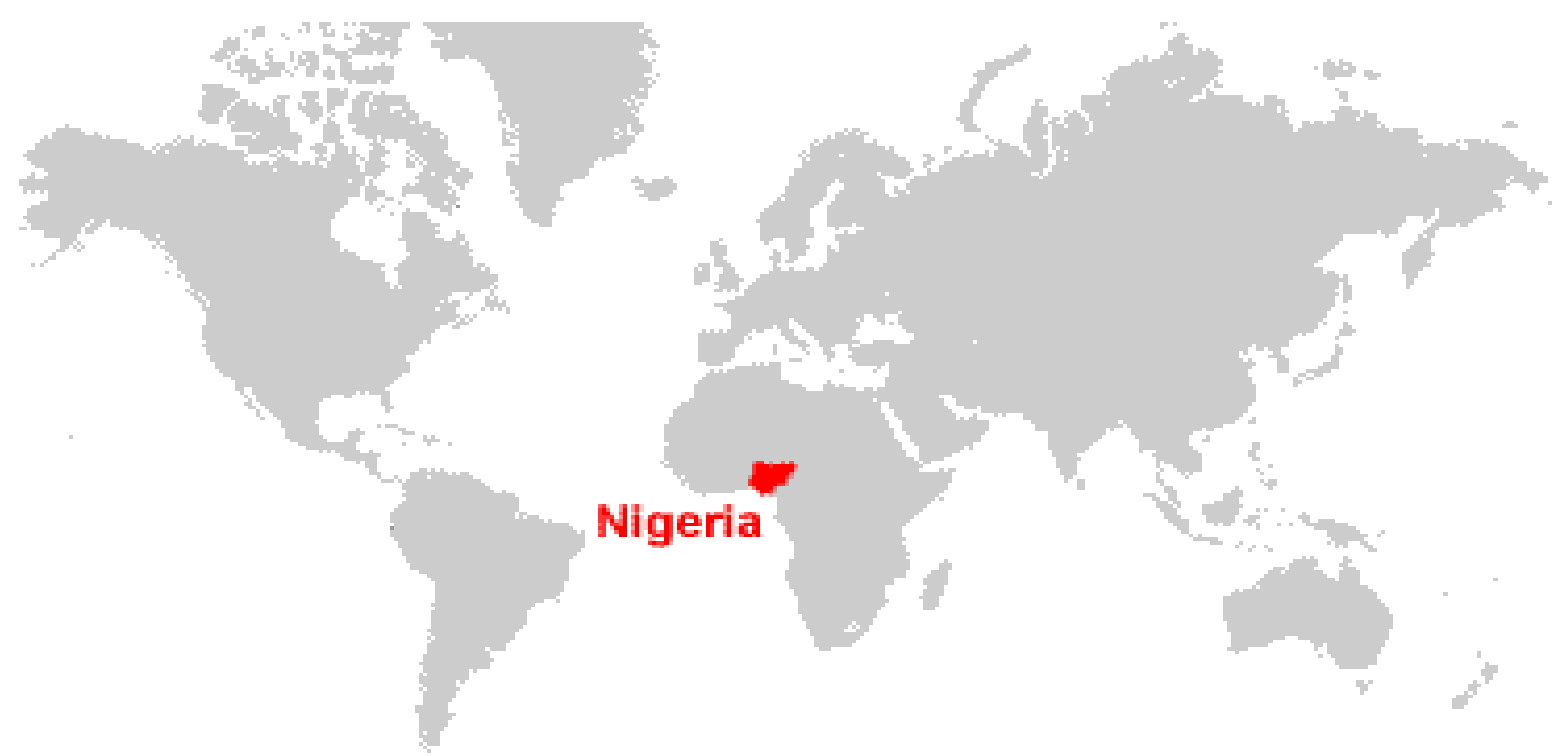

Figure 1. World map showing Nigeria

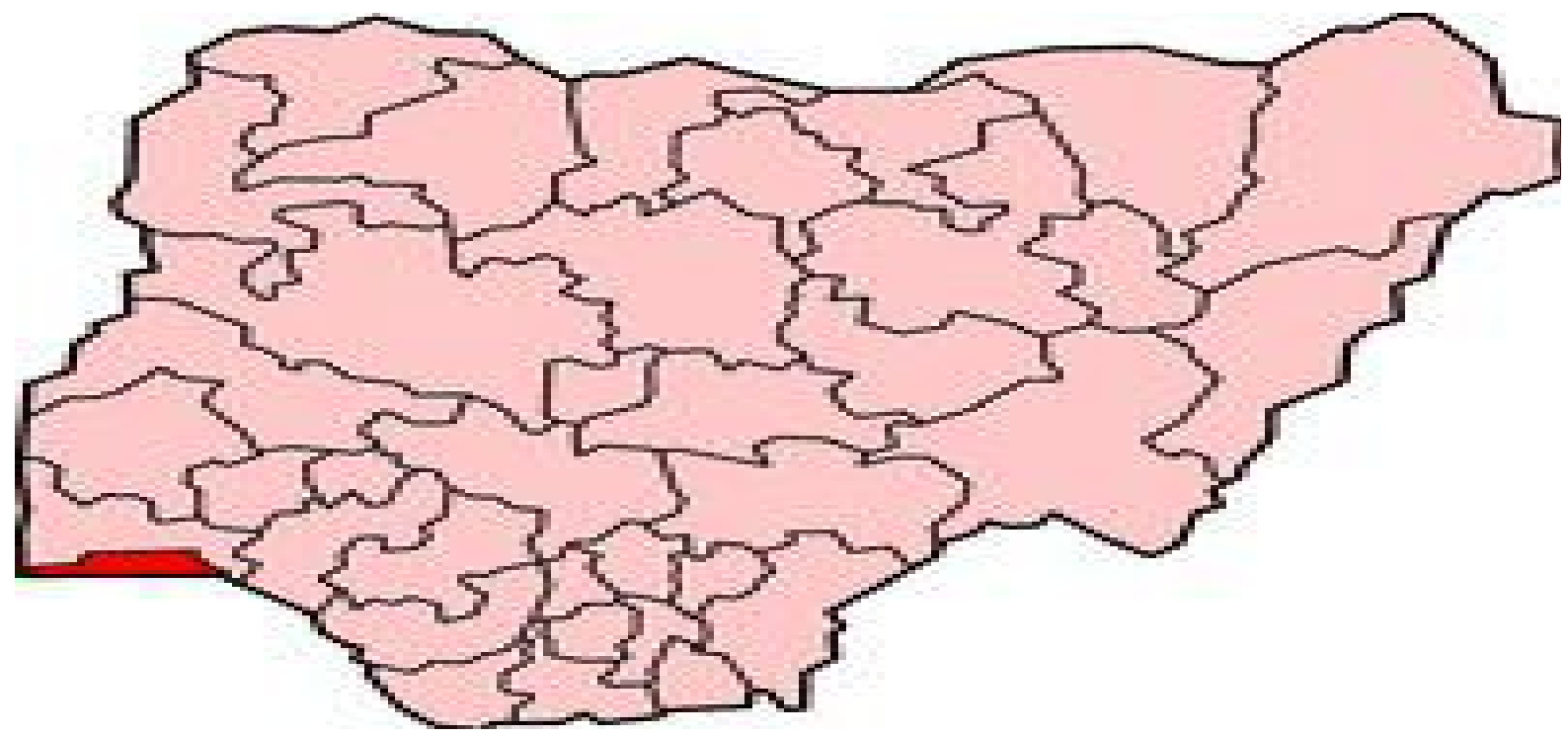

Figure 2. Map of Nigeria showing Lagos State

Lagos State in Nigeria lies approximately between longitudes 2042' - 3042' East and latitudes 6022' - 6052' North. The southern boundary of the State lies along the Atlantic coastline while its northern and eastern boundaries are shared with Ogun State. On the western side the boundary is bordered by the Republic of Benin. Its size is about $3,577 \mathrm{~km}^{2}$, has about $180 \mathrm{~km}$ coastline and is about $4.6 \mathrm{~m}$ above sea level (A.S.L.) . It has about 
$22 \%$ water coverage consisting of rivers, lagoons, creeks and streams (LAWMA, 2011).

The population is currently estimated at 21 million with a population density of about $6,030 / \mathrm{km}^{2}$. It has 20 LGAs \& 37 LCDAs with over 2,600 communities. The megacity is home to trans-national corporations and national conglomerates headquarters and has the largest Stock Exchange in West Africa. It is home to 200 firms (out of 250) listed on NSE . It has over 2000 industrial complexes ( $65 \%$ of country total), 10,000 commercial ventures (70\% of country total) and 22 industrial estates \& several business districts. Also known with the sobriquet "Centre of Excellence", it contributes about $31.89 \%$ to national gross domestic product GDP - (2004), $60 \%$ of nation's value added manufacturing and $65 \%$ of nation's value added tax VAT.

GEOLOGICAL SETTINGS
The geology of the landfill areas suitable for landfill gas exploitation is essentially that of the Oligocene to Pleistocene Coastal Plain Sands. The name Coastal Plains Sands (now also called Benin Formation) was introduced by Tattam (1943) to describe the extensive red earths and loose, ill-sorted sands underlying the Recent deposits of the Niger Delta. The nomenclature is well established in the stratigraphy of the Delta and it has been retained in the south-western coastal sedimentary basin, although the abundance of clays in the Formation in this area do not make it entirely appropriate (Jones and Hockey, 1964).

The Coastal Plains Sands consist of soft, very poorly sorted, clayey sands, pebbly sands, sandy clays, pockets of shale, and rare, thin lignites. They are indistinguishable in the field from much of the Ilaro Formation and from the basal continental beds of the Abeokuta Formation (Fig. 3)

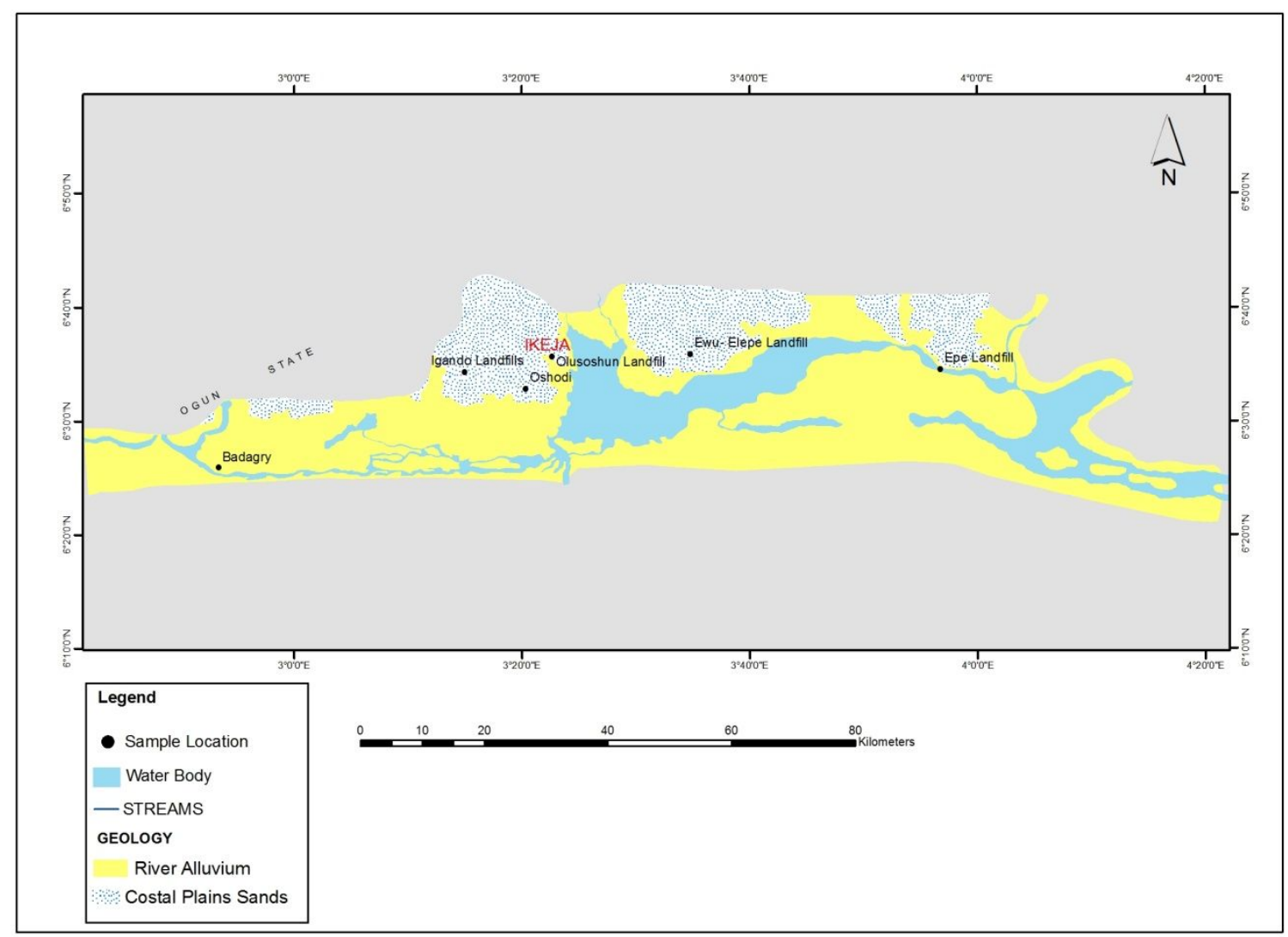

Figure 3. Map of the geology of Lagos State showing the landfill locations and other areas).

\section{ENVIRONMENTAL BENEFITS OF METHANE CAPTURE}

Methane has 23 times the globe warming potential of carbon dioxide (IPCC, Third Assessment Report TAR 2001). According to Scheehle et al. (2006), an estimated $12 \%$ of methane emissions are caused by landfilling of wastes. Another study by Melack et al.( 2004) and Ramos et al. (2006) noted that about $4 \%$ of global warming scenario is being induced by methane emissions from man-made waste dams. Furthermore, a study by Lindberg et al found methyl mercury in the water vapour that condensed out of the gas emanating from a Florida landfill. Although even mercury in its elemental form is toxic, its most poisonous embodiment is methyl mercury, the result of a chemical modification by bacteria.This collaborates previous finding in wetlands, where researchers had previously identified certain bacteria that methylate natural, inorganic mercury derived from minerals. This same family of microbes resides in landfill. (Science News, 2001).

The IPCC (2013) Report asserted with about 95\% certainty that humans are the dominant factor in view of climate change since the 1950s. Therefore, the ability to capture methane from the Lagos landfills will help to utilise this waste to energy (WTE) potential and mitigate contributory effects to global warming and its attendant consequences. 
Landfill gas (LFG) exploitation is one of the critical areas of a modern integrated landfill. In this regard, portions of the Olusosun landfill have been fitted with underground LFG collection pipes for eventual exploitation (Fig. 6). All the landfills except Epe have recurring incidences of spontaneous fire outbreaks owing to the ignition of the released over-pressured-methane by solar insolation and/ or electromagnetic sparks during lightning.

Discharge of Green House Gases (GHGs) and the management of municipal solid waste (MSW) continue to be a major challenge particularly in growing economies. However, these are resources which can be converted to green energy (Yedla S, et al (2001). Landfill gas is continuously generated due to the anaerobic degradation of the organic fraction of solid waste. Therefore, in a landfill in which an extracting system is not installed, there will be an over-pressure that will force the biogas to be released into the atmosphere (Surroop and Mohee, 2011)

In the Lagos landfills, explosions often occur with attendant risks on surrounding buildings and manholes where the gas accumulated may be accidentally ignited by use of open fire and electrical sparks. To reduce explosion hazard at landfill and to reduce emissions of methane, landfill operators can either collect and flare the gas or harness it to recover energy. Both options address local air quality and safety concern but the second option can capitalise on the energy value of landfill gas and displace the use of fossil fuel. Offsetting the use of fossil fuel to generate electricity reduces further greenhouse gas emissions and pollutants, including sulphur dioxide, which is a major contributor to acid rain (Yip and Chuan (2008).

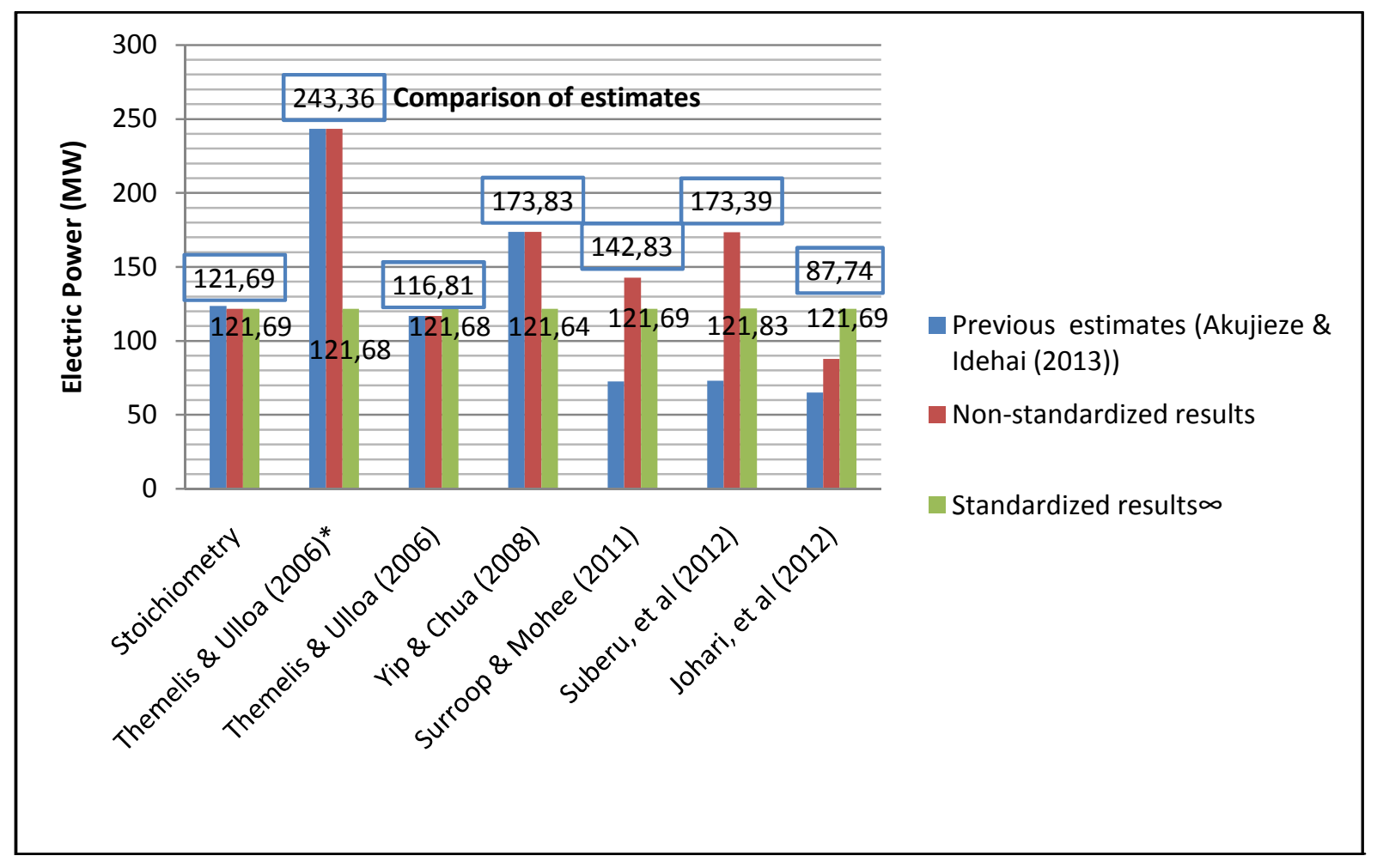

$\infty=$ ( standardized using $50 \%$ of LFG as methane, recoverable methane set as $50 \%$, engine capacity= $30 \%$ )

Figure 4. Comparisons of power estimates of the landfill gas electricity capacity of the Lagos Area. 


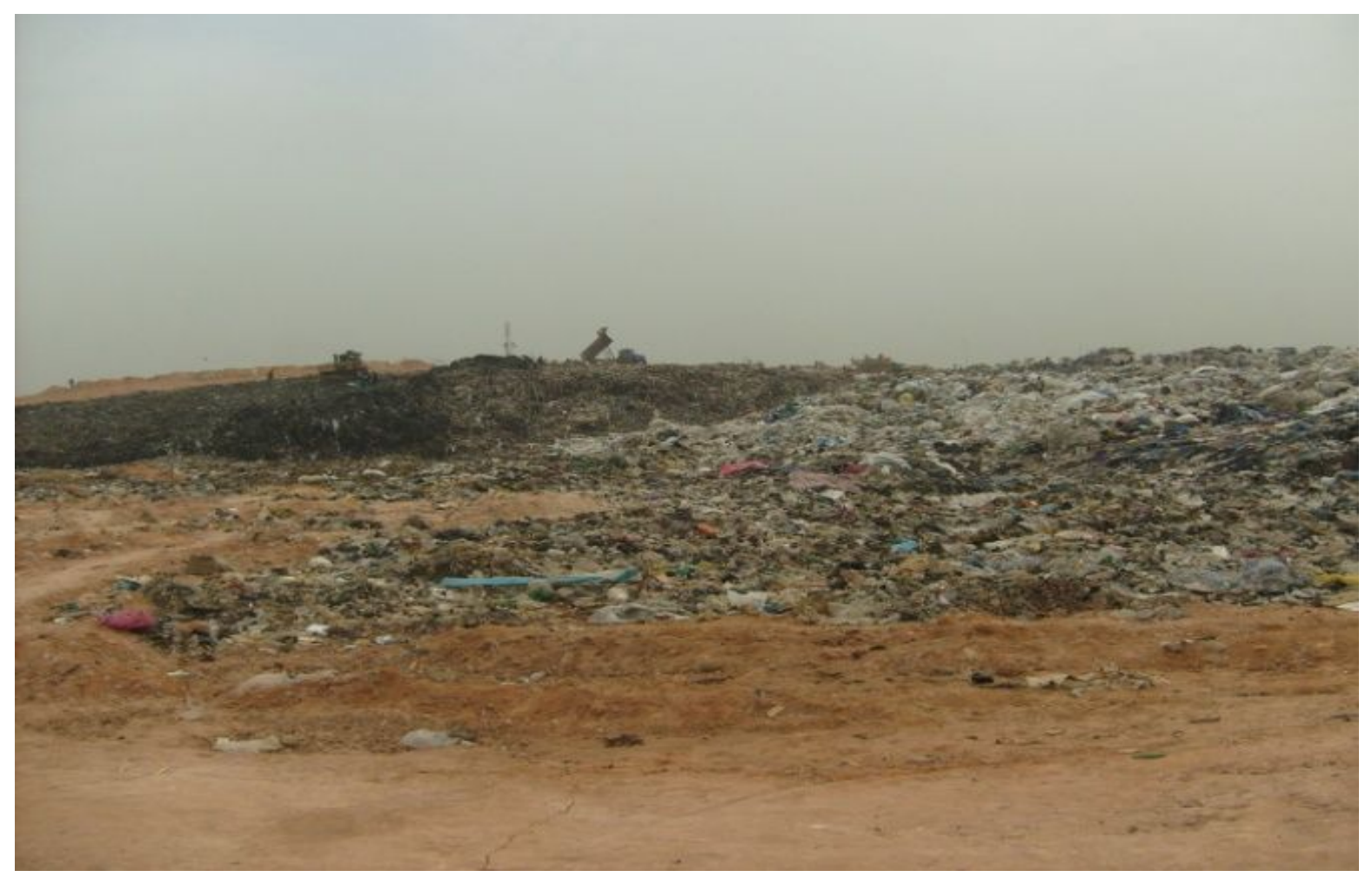

Figure 5. Partially capped areas of Olusosun Landfill.

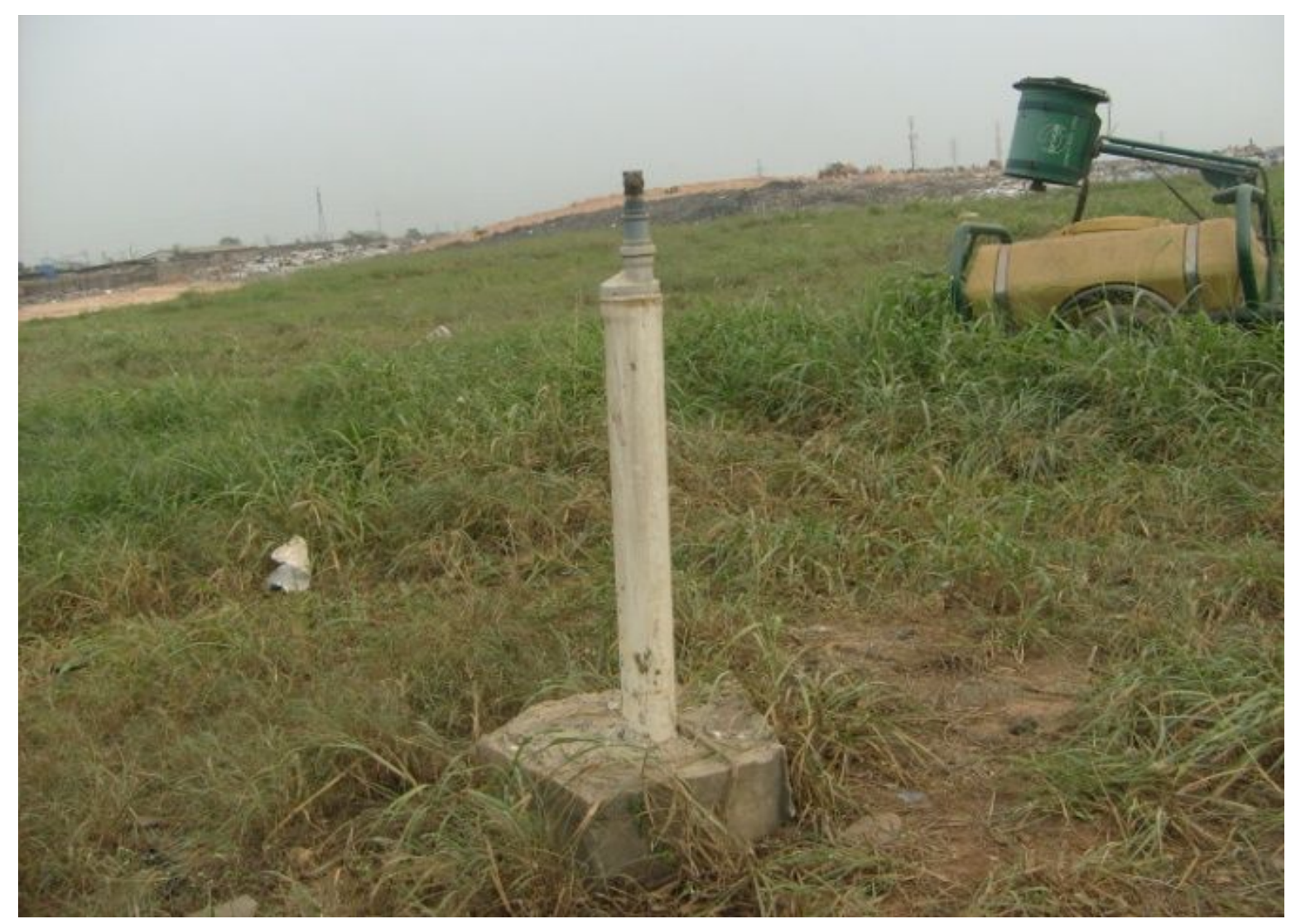

Figure 6. A well-head for LFG capture at Olusosun 


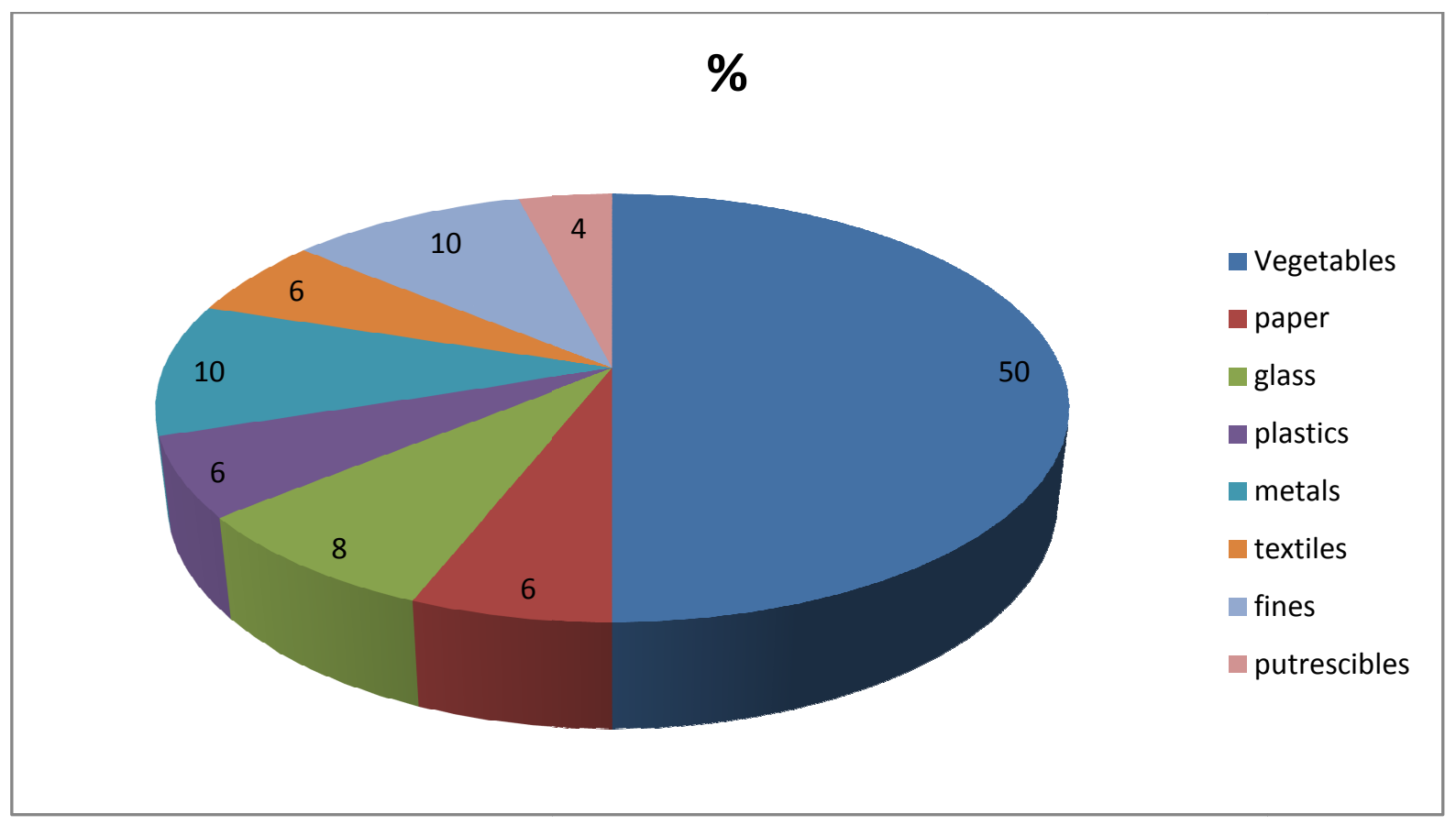

Figure 7. Characterization of the Lagos waste by weight (after LAWMA, 2011)

\section{THEORY AND METHODS}

Estimation of the landfill gas and Electricity Potential of Lagos Using stoichiometry

Biomass materials which include paper, food and yard wastes, wood, leather, cotton and wool, constitute about $60 \%$ of the Lagos municipal solid waste ( after LAWMA, 2011). The rest are petrochemicals (e.g. plastics), inorganic materials such as metals, glass, etc. According to Themelis and Ulloa (2006), by using the ultimate atomic analysis of various types of wastes and the atomic weights of the respective elements, it was possible to derive the composite molecular formulae corresponding to mixed food wastes and paper. Thus:

Mixed food and green wastes: $\mathrm{C}_{6} \mathrm{H}_{9.6} \mathrm{O}_{3.5} \mathrm{~N}_{0.28} \mathrm{~S}_{0.2}$.

Mixed paper: $\mathrm{C}_{6} \mathrm{H}_{9.6} \mathrm{O}_{4.6} \mathrm{~N}_{0.036} \mathrm{~S}_{0.01}$.

If the minor elements are excluded, the average molecular structure of organic compounds in municipal solid waste (MSW) can be approximated by the molecular composition $\mathrm{C}_{6} \mathrm{H}_{10} \mathrm{O}_{4}$. It is interesting to note that this composition corresponds to the structural formula of at least ten organic compounds, such as ethyl butanedioic acid, succinic acid, adipic acid, ethylene glycol diacetate, etc.

Shortly after MSW is landfilled, the organic components start to undergo biochemical reactions. In the presence of atmospheric air (that is near the surface of the landfill), the natural organic compounds are oxidized aerobically, a reaction that is similar to combustion because the products are carbon dioxide and water vapour.

The black colour of the leachate in conjunction with the lack of sunlight inside the leachate reservoir makes the oxygen levels to decrease markedly leading to the appeasement of anaerobic conditions. (Junqueira, et al., 2000). This anaerobic process is the essential reaction in the landfill and takes place in three stages. Firstly, the complex organic matters are hydrolyzed by fermentative bacteria into soluble products (like glucose). Secondly, these molecules are converted by acid forming bacteria to simple organic acids, carbon dioxide and hydrogen; the principal acids produced are acetic acid (ethanoic acid), propanoic acid, butanoic acid and ethanol. Finally, in the third stage, methane is formed by methanogenic bacteria, either by breaking down the acids to methane and carbon dioxide, or by reducing carbon dioxide with hydrogen. The second and third reactions can be represented as follows:

$\mathrm{C}_{6} \mathrm{H}_{12} \mathrm{O}_{6}=2 \mathrm{C}_{2} \mathrm{H}_{5} \mathrm{OH}+2 \mathrm{CO}_{2} \quad$ (Acetogenesis)

$\mathrm{CH}_{3} \mathrm{COOH}=\mathrm{CH}_{4}+\mathrm{CO}_{2} \ldots \quad$ (Methanogenesis)

$\mathrm{CO}_{2}+4 \mathrm{H}_{2}=\mathrm{CH}_{4}+2 \mathrm{H}_{2} \mathrm{O} \ldots \quad$ (Methanogenesis)

The maximum amount of landfill gas (LFG) that may be generated during anaerobic decomposition can be estimated from simplified chemical equation. The composite molecular formula of the biodegradable component of the Lagos MSW can be given as:

$\mathrm{C}_{6} \mathrm{H}_{10} \mathrm{O}_{4} \quad+1.5 \mathrm{H}_{2} \mathrm{O}=3.25 \mathrm{CH}_{4}+2.75 \mathrm{CO}_{2}$

adipic acid (i.e. waste)

The LFG produced here contains about $50-54 \% \mathrm{CH}_{4}$ and $40-46 \% \mathrm{CO}_{2}$ and other minor products such as ammonia and hydrogen sulphide. The reaction progresses better in the presence of excess water, which is the principal reagent (4) and a $\mathrm{pH}$ of about 7. Equation (4) shows that $5.4 \mathrm{~kg}$ of the waste can react with $1 \mathrm{~kg}$ of water (since MW of the waste is 146 and that of water 18) Given: $417 \mathrm{~kg}$ of adipic acid comes from I tonne of MSW

Thus in the Lagos Landfills: 
1 tonne MSW $\rightarrow 0.6$ tonne biomass $\rightarrow 0.417$ tonne

$$
\mathrm{C}_{6} \mathrm{H}_{10} \mathrm{O}_{4} \rightarrow \mathrm{x} \text { tonne } \mathrm{CH}_{4}
$$

By implication:

$417 \mathrm{~kg} \mathrm{C}_{6} \mathrm{H}_{10} \mathrm{O}_{4} \rightarrow 149 \mathrm{~kg} \mathrm{CH}$

Note that :

Molecular weight (MW) of $\mathrm{C}_{6} \mathrm{H}_{10} \mathrm{O}_{4}=146$

$\therefore 146 \mathrm{~kg} \mathrm{C}{ }_{6} \mathrm{H}_{10} \mathrm{O}_{4} \rightarrow 1 \mathrm{Kmol} \mathrm{C}_{6} \mathrm{H}_{10} \mathrm{O}$

$\mathrm{MW} \mathrm{CH}_{4}=16$

$\therefore 16 \mathrm{~kg} \mathrm{CH}_{4} \rightarrow 1 \mathrm{Kmol} \mathrm{CH}_{4}$

From gas laws:

$16 \mathrm{~kg} \mathrm{CH}_{4} \rightarrow 1 \mathrm{Kmol} \mathrm{CH}_{4} \rightarrow 22.4 \mathrm{Nm}^{3} \mathrm{CH}_{4}$

$1 \mathrm{~kg} \mathrm{CH}_{4} \rightarrow 1.4 \mathrm{Nm}^{3} \mathrm{CH}_{4}$

1tonne $\mathrm{CH}_{4} \rightarrow 1,400 \mathrm{Nm}^{3} \mathrm{CH}_{4}$

0.149 tonneCH $4 \rightarrow 208.6 \mathrm{Nm}^{3} \mathrm{CH}_{4}$

Summarily:

1tonne MSW $\rightarrow 0.417$ tonne $\quad \mathrm{C}_{6} \mathrm{H}_{10} \mathrm{O}_{4} \rightarrow 0.149$ tonne $\mathrm{CH}_{4} \rightarrow 208.6 \mathrm{Nm}^{3} \mathrm{CH}_{4}$

9261tonneMSW $\rightarrow 3861.837$ tonneC ${ }_{6} \mathrm{H}_{10} \mathrm{O}_{4} \rightarrow 1379.889$ tonn $\mathrm{eCH}_{4} \rightarrow 1932261.8 \mathrm{Nm}^{3} \mathrm{CH}_{4}$

However, in actuality, the volume of recoverable methane in landfills is about $50-70 \%$ that generated.

Using the lower limit, (10) becomes:

$\therefore 1$ tonne $\mathrm{MSW} \rightarrow 0.417$ tonne $\mathrm{C}_{6} \mathrm{H}_{10} \mathrm{O}_{4} \rightarrow 0.0745$ tonne $\mathrm{CH}_{4} \rightarrow 104.3 \mathrm{Nm}^{3} \mathrm{CH}_{4}$

Hence daily in the Lagos area:

9261tonneMSW $\rightarrow$ 3861.837tonneC ${ }_{6} \mathrm{H}_{10} \mathrm{O}_{4} \rightarrow 689.945$ tonne $\mathrm{CH}_{4} \rightarrow 966130.9 \mathrm{Nm}^{3} \mathrm{rCH}_{4}$

The energy density of natural gas is about 34.6- 38.3 MJ per cubic metre. This is about 9.6-10.6 KWh

Recall that: $1 \mathrm{~m}^{3}$ of natural gas $=35.32 \mathrm{ft}^{3}$ (also, $1 \mathrm{ft}^{3}$ of natural gas $=1020 \mathrm{BTU}$ )

$1 \mathrm{~m}^{3}$ of natural gas $=35.32 \times 1020 \mathrm{BTU} / \mathrm{m}^{3}=36,026 \mathrm{BTU}$

Hence: $1 \mathrm{KWh}=3413 \mathrm{BTU}$

Applying the lower limit, the electrical power potential $E_{p}$ of $1 \mathrm{~m}^{3}$ of methane $=9.6 \mathrm{KWh}$.

Similarly, the power generation potential $\left(\mathrm{P}_{\mathrm{gp}}\right)=$ $9.6 / 24 \mathrm{KW}=0.4 \mathrm{KW}$.

Thus,

9261 tonnes $\mathrm{MSW} \rightarrow 3861.837$ tonnes $\mathrm{C}_{6} \mathrm{H}_{10} \mathrm{O}_{4} \rightarrow 689.945$ tonnes $\mathrm{CH}_{4} \rightarrow 966130.9 \mathrm{Nm}^{3} \mathrm{CH}_{4} \rightarrow 386.45 \mathrm{MW}$

Using the upper limit,

the electrical power potential $\left(E_{p}\right)$ of $1 \mathrm{~m}^{3}$ of methane $=10.55 \mathrm{KWh}, \mathrm{P}_{\mathrm{gp}}=0.43958 \mathrm{KW}$

Thus,

9261tonnesMSW $\rightarrow$ 3861.837tonnes $\mathrm{C}_{6} \mathrm{H}_{10} \mathrm{O}_{4} \rightarrow 689.945$ ton nesCH $4 \rightarrow 966130.9 \mathrm{Nm}^{3} \mathrm{CH}_{4} \rightarrow 424.69 \mathrm{MW}$
(Note: the mean $\mathrm{E}_{\mathrm{p}}$ of $1 \mathrm{~m}^{3}$ of methane $=36.45 \mathrm{MJ} \rightarrow$ $0.00042 \mathrm{MW}$ ). Furthermore, the efficiencies of internal combustion engines hover around 30\%. Therefore, the conservative optimum electrical power that can be generated from the existing parameters in Lagos State is about 115.94MW-127.41MW. (Mean = 121.69 MW, mean of $1 \mathrm{~m}^{3} \mathrm{CH}_{4}=0.000126 \mathrm{MW}$ )

\section{STANDARDIZATION OF THE LAGOS LFG ELECTRICITY} POTENTIAL

In 2006, Themelis and Ulloa gave the following theoretical estimation for methane generation from municipal solid wastes (MSW) in USA:

1 tonnes $\mathrm{CH}_{4} \rightarrow 1,400 \mathrm{Nm}^{3} \mathrm{CH}_{4}$

(This is $100 \%$ of theoretical/ stoichiometry)

(Recall: 1 tonne MSW $\rightarrow$ 0.417tonne $\mathrm{C}_{6} \mathrm{H}_{10} \mathrm{O}_{4} \rightarrow$ 0.149tonne $\mathrm{CH}_{4} \rightarrow 208.6 \mathrm{Nm}^{3} \mathrm{CH}_{4}$.)

By juxtaposition, at $100 \%$ recovery of generated methane, in the Lagos area the derivable maximum electricity using internal combustion engines of $30 \%$ will be: $243.36 \mathrm{MW}$

However in practice, in many of the US landfills:

1 tonne MSW $\rightarrow 100 \mathrm{Nm}^{3} \mathrm{CH}_{4}$

(i.e. about $48 \%$ of theoretical ).

This is supported by the estimation that about $50 \%$ of produced methane is recoverable. This means that an electricity of $116.81 \mathrm{MW}$ is achievable.

(2) Yip \& Chuan (2008) in Malaysia estimated that

1 tonnes $\mathrm{CH}_{4} \rightarrow 1,000 \mathrm{~m}^{3} \mathrm{CH}_{4}$

(about 71.4\% of theoretical)

Given similar situation in Lagos, $173.83 \mathrm{MW}$ of electrical power is derivable.

(3) Using Surroop and Mohee (2011) in Mauritius estimates:

1tonne $\mathrm{MSW} \rightarrow 122 \mathrm{~m}^{3} \mathrm{CH}_{4}$

Where methane is $50 \%$ LFG. This is about $58.5 \%$ of theoretical. Corollary, a power of $142.33 \mathrm{MW}$ is expected in Lagos.

(4) Comparison with Suberu, et al (2012) in Malaysia shows that the power and energy potential of the Lagos landfills can be estimated as follows:

$E p=\mathrm{H}_{V} \times \mathrm{W} \times 0.0011628$

$P_{g p}=E p / 24$

Where

$E_{p}=$ Energy potential $(\mathrm{kWh})$

$P_{g p}=$ Power generation potential $(\mathrm{kW})$

$H_{V}=$ Calorific value of the waste (kcalkg-1)

$W=$ Weight of the waste (tonne)

Calorific value (Higher heating value) used for the purpose of this calculation $=905 \mathrm{kcal} / \mathrm{kg}$

Hence,

$E_{p}=9745.7 \mathrm{MWh}$

$P_{g p}=406.1 \mathrm{MW}$ 
If generators of $30 \%$ efficiency are installed, the amount of actual electricity (or electrical power) that would be generated is

Power $(\mathrm{P})=0.3 P_{g p}$

$$
\mathrm{P}=121.83 \mathrm{MW}
$$

(Note that Suberu, et al., (2012) estimated a power potential of $483 \mathrm{MW}$ from a 2008 Lagos population of about 17.55 million people. Consequently, 577.95 MW would be currently derivable as potential power output, with actual power output of $173.39 \mathrm{MW}$. However, Idehai (2014), observed that this figure is not completely supported by stoichiometry and actuality).

5). Taherzadeh (2010) in Sweden posited that the MSW of $150,000,000$ inhabitants can be converted to about 1,000$5,000 \mathrm{MW}$ electricity, depending on the technology used.

Thus in the Lagos Area, :

$21,000,000 \rightarrow 140 \mathrm{MW}$ (lowerlimit)

21,000,000 $\rightarrow 700 \mathrm{MW}$ (upperlimit)

The lower limit of $140 \mathrm{MW}$ is more plausible in the Lagos area.

6) IPCC Equation Derived: The electrical power capacity of the Lagos LFG can be estimated using the formula below:

$\mathrm{CH}_{4}$ emissions (tonne) $=\mathrm{MSW}_{\mathrm{T}} \times \mathrm{MSW}_{\mathrm{F}} \times \mathrm{MCF} \times \mathrm{DOC} \times$ $\mathrm{DOC}_{\mathrm{F}} \times \mathrm{F} \times 16 / 12$

where :

$\mathrm{MSW}_{\mathrm{T}}=$ total MSW generated (tonnes)

$\mathrm{MSW}_{\mathrm{F}}=$ fraction of MSW disposed of to landfills

$\mathrm{MCF}=$ methane correction factor

DOC $=$ fraction of degradable organic carbon

$\mathrm{DOC}_{\mathrm{F}}=$ fraction of total DOC that actually degrades

$\mathrm{F}=$ fraction of methane in LFG.

$\mathrm{DOC}=0.4 \mathrm{P}+0.15 \mathrm{~K}+0.3 \mathrm{~W}$

Where:

$\mathrm{P}=$ fraction of papers in MSW,

$\mathrm{K}=$ fraction of kitchen garbage in MSW

$\mathrm{W}=$ fraction of woods/leaves in MSW.

Furthermore, the DOC F should be considered because the biodegradation of DOC does not occur totally over a long period; therefore, a default value of 0.77 can be used.

Using this to compute for Lagos:

$\mathrm{CH}_{4}$ emissions (tonnes) $=130,843$ tonnes per year

$$
=358.47 \text { tonnes per day }
$$

Therefore, 358.47 tonnes $\mathrm{CH}_{4} \rightarrow 63.22 \mathrm{MW}$

7). Akujieze and Idehai (2013) made series of comparisons with some of the aforementioned authors. However, the results obtained were not subjected to the present standardization procedures (Fig. 4).

The Lagos LFG Economic Potential.

Johari, et al (2012) estimated that in Malaysia:
8,196,000 tonnes MSW (of $61.17 \%$ biomass) $\rightarrow$ 310,220 tonnesCH $\mathrm{H}_{4}$

1tonne MSW (of $61.17 \%$ biomass $\rightarrow 0.03785$ tonne $\mathrm{CH}_{4}$

1tonne $\mathrm{MSW}$ (of $60 \%$ biomass) $\rightarrow 0.037126$ tonne $\mathrm{CH}_{4}$ ... (33)

Thus, daily in Lagos :

$\therefore 9,261$ tonnes of MSW of $60 \%$ biomass $\rightarrow 343.826$ tonnes of $\mathrm{CH}_{4}$

Therefore in a year in Lagos,

$3,380,000$ tonnes of MSW $\rightarrow 125,496.5$ tonnes of $\mathrm{CH}_{4}$

Given: In Malaysia; 310,220 tonnes $\mathrm{CH}_{4} \rightarrow 1.9$ million MWh

Hence,

$\mathrm{MWh} \rightarrow 0.2552 \mathrm{MW}$

1 tonne $\mathrm{CH}_{4}$

MWh $\rightarrow 0.2552 \mathrm{MW}$

343.826 tonnes $\mathrm{CH} \rightarrow 2105.83$
$\mathrm{MWh} \rightarrow 87.74 \mathrm{MW}$

Therefore in one year in Lagos:

$125,496.5$ tonnesCH $\mathrm{CH}_{4} \rightarrow 768,626.7 \mathrm{MWh}$

(The implication in the Malaysia scenario is that one tonne of methane yields $0.2552 \mathrm{MW}$ of electricity. This means that although the recoverable methane was about $50 \%$ of actuality or about $25 \%$ of theoretical, the efficiency of the engine was about $43.4 \%$. This efficiency value seems quite high given common efficiency trends of related engines).

Comparing this with stoichiometry:

1 tonne MSW $\rightarrow$ 0.417tonne $\mathrm{C}_{6} \mathrm{H}_{10} \mathrm{O}_{4} \rightarrow 0.0745$ tonne $\mathrm{CH}_{4} \rightarrow 0.01314 \mathrm{MW}$

9261 tonne MSW $\rightarrow$ 689.9445 tonne $\mathrm{CH}_{4} \rightarrow 121.69$

$\mathrm{MW} \rightarrow 2920.56 \mathrm{MWh}$

(i.e. 1 tonne methane yields $0.1764 \mathrm{MW}$ )

\section{Estimated Derivable Electricity Revenue}

... (28) Given: In Malaysia and Nigeria, electricity tariff is about : $1 \mathrm{KWh} \rightarrow$ US $\$ 0.1$

$1 \mathrm{MWh} \rightarrow$ US $\$ 100$.

Using the concepts of Johari, et al., (2012), annually in Lagos:

3,380,000 tonnes $\quad$ MSW $\rightarrow 125,496.5 \quad$ tonnes

$\mathrm{CH}_{4} \rightarrow 768,626.7 \mathrm{MWh} \rightarrow \mathrm{US} \$ 76.86$ million

Whereas by stoichiometry,

3,380,000 tonnes MSW $\rightarrow 251,829.74$ tonnes $\mathrm{CH}_{4}$

$\rightarrow 1,066,004.4$ MWh $\rightarrow$ US\$ 106.6 million

Projected Carbon Credit from certified emission reduction CER)

From (35),

3,380,000 tonnes of MSW $\rightarrow 125,496.5$ tonnes $\mathrm{CH}_{4}$

The greenhouse warming potential GWP of $\mathrm{CH}_{4}$ is 23 times that of $\mathrm{CO}_{2}$ (IPCC, Third Assessment Report TAR, 2001). Thus

$125,496.5$ tonnes ofCH $4 \rightarrow 2,886,419.5$ tonnes $\mathrm{CO}_{2}$ 
Given: Johari (2012): In Malaysia, Carbon credit : US $\$ 13.05 /$ tonne of $\mathrm{CO}_{2}$ Therefore, 2,886,419.5 tonnes of $\mathrm{CO}_{2} \rightarrow$ US\$ 37.67 million.

However from stoichiometry, 251,829.74 tonnes $\mathrm{CH}_{4} \rightarrow 5,792,084.02$ tonnes of $\mathrm{CO}_{2} \rightarrow$ US\$ 75.59 million

Estimated derivable revenue: adding (39) and (42) $=$ US $\$ 114.53$ million (about N17.87billion )

adding (40) and (43) = US\$ 182.19 million (about N28.42 billion)

\section{ACKNOWLEDGEMENT}

The authors are profoundly grateful to the Managing Director of LAWMA : Mr Ola Oresanya, and his able crew for the immense co-operation enjoyed all through the course of the geological site invesigation. The support enjoyed from the staff of LASEPA especially; Engr. Adebisi O.G. Adesina (the G.M), Dr. (Mrs.) Adetola W. Onisarotu, Benjamin and others, is worthy is adulation.

\section{CONCLUSION}

Estimations of the landfill gas (LFG) and electricity potential of Lagos by comparisons with those of previous workers in other parts of the world gave values between 63.22- 700MW. The existing disparities and ambiguities in values were significantly reduced by a consideration of stoichiometry and actuality. The standardization here attempted can be further developed to create a credible model for the eventual exploitation of this resource in Lagos and other parts of the world. By subjection to this suggested standardization, the projected electricity is placed at 121.69 MW and this can power over 121,690 homes and provide electricity to a human population of over 0.73 million. Expected annual yield from electricity tariff is about US\$ 106.6 million with an accruable US\$ 75.59 million/ year from carbon credit. The concomitant effects are expected to be exponentially higher in terms of the reduction of green house gases and the mitigation of other environmental hazards.

\section{REFERENCES}

Ahmed,SI, Johari, A.,Hashim, H., Ramli, M., and Alkali, H. (2013).Landfill Gas and Its Renewable Energy Potentials in Johor,Mal aysia

International Journal of Emerging Trends in Engineering and Deve lopment Issue 3: 1-15
Ahmed, S.I., Johari, A.,Hashim, H., Alkali, H., and Ramli, M. (2011). Renewable Energy andcarbon Reduction Potentials of Mu nicipal Solid Waste in

Malaysia, IEEE FirstConference on Clean Energy and Technology CE: 280286.

Akujieze, C.N., and Idehai, I. M.(2013). Estimation of the Electricity Energy Potentials from the Land Fill Gas (LFG) of Municipal Solid Waste (MSW) \& Environmental Benefits in Lagos State, Nigeria. Journal of Environmental Engineering. Vol. 2, No 2 (in press)

Idehai, I. M.(2013). Municipal Solid Waste Disposal in Lagos: Effects on the Environment, and Partial Estimation of the Landfill Gas and Recyclable Potentials. M.Sc thesis, University of Benin.

IPCC, Intergovernmental Panel on Climate Change(2006).Guidelines for National Greenhouse Gas Inventories. :3.1-3.40.

Johari, A., Ahmed, S.I., Hashim, H., Alkali, H., and Ramli, M. (2012): Economic and Environmental Benefits of Landfill Gas from Municipal Solid Waste in Malaysia Renewable and Sustainable Energy Reviews 16 : 2907- 2912

Jones, H.A. and Hockey, R. D. (1964). The Geology of Part of S. W. Nigeria, Geol. Surv. Nigeria, Bull 31, pp87.

Kamalan, H., Sabour, M., and Shariatmadari, N. (2011). A review on available landfill gas models. J. Environ. Sci. Technol., 4: 79-92.

LAWMA (2011): Sustainable Solid Waste Management in Developing Countries: Lagos as a Case Study. LAWMA. :111 www.lawma.gov.ng).

Melack, J.M., Hess, L.L., Gastil, M., Forsberg, B.R., Hamilton, S.K., and Lima, I.B.T. (2004)."Regionalization of methane emissions in the Amazon Basin with microwave remote sensing", Global Change Biology, $41: 530-544$.

Ozakaya, B., Demir, A., and Bilgili, M.B. (2006). Neural Network Prediction Model for the Methane Fraction in Biogas from FieldScale Landfill Bioreactors. Environ. Modelling Software, 22: 815822.

Ramos, F.M., Lima, I.B.T., Rosa, R.R., Mazi, E.A., Carvalho, J.C., and Rasera, M.F.F.L., (2006). Extreme event dynamics in the methane ebullition fluxes from tropical reservoirs Geographical Research Letters,33: 1- 21.

Report of the United Nations Conference on Environment and Development (Rio De Janeiro, 3-14 June 1992). http://www.un.org/geninfo/bp/enviro.html (accessed on March 11, 2014)

Scheehle, E., Godwin, D., and Ottinger, D. (2006). Global anthropogenic non- $\mathrm{CO}_{2}$ greenhouse gas emission:1990-2020, USEPA 430-R-06$003 ; 2006$, pp. 274.

Science News, (2001). Volume 160, No. 1 : 4 http://www.phschool.com/science/science_news/articles/landfil ls_mercury_toxic.html (Accessed on February 09, 2014)

Suberu, M.Y., Mokhtar, A.S., and Bashir, N. (2012). Renewable Power Generation Opportunity From Municipal Solid Waste: A Case Study of Lagos Metropolis (Nigeria) Journal Of Energy Technologies And Policy ISSN 2224-3232 Vol.2, No.2, :1-15.

Surroop, D. and Mohee, R. (2011). Power Generation from Landfill Gas: 2nd International Conference On Environmental Engineering And Applications IPCBEE Vol.17 (C) IACSIT Press, Singapore

Taherzadeh, M. (2010). Energy Generation from Wastes. Vetenskap for Profession, 10:73-38

Themelis, N.J. \& Ulloa P.A. (2006). Methane Generation in Landfill. Renewable Energy, 32: 1243-1257.

USEPA (1996) Turning a Liability into an Asset: A Landfill Gas-To-Energy Project Development Handbook, Landfill Methane Outreach Program, EPA.

Yedla, S. and Parikh, 1.K. (2001): Economic Evaluation of a Landfill System with Gas Recovery for Municipal Solid Waste Management: A Case Study, Int. J. Environment and Pollution, Vol. 15, No.4: 433-447.

Yip,C.H. and Chua,K.H. (2008).An Overview on the Feasibility of Harvesti ng Landfill Gas from MSW to Recover Energy.ICCBT. F(28): 303310 . 